\title{
Analysis of Student's Spatial Ability in terms of Van Hiele's Thinking Stages in Problem Based Learning
}

\author{
Hairunnisah Tanjung ${ }^{1}$, Bornok Sinaga ${ }^{2}$, Abil Mansyur ${ }^{3}$ \\ ${ }_{1,2,3}$ Universitas Negeri Medan, Indonesia \\ hairunnisahtanjung@gmail.com,bsinaga@unimed.ac.id,abilmpanjaitan@gmail.com
}

\begin{abstract}
This study aims to analyze students 'spatial mathematical abilities in terms of Van Hiele's thinking stages in problem-based learning models, as well as to find out the number of difficult indicators of students' mathematical spatial abilities in terms of Van Hiele's thinking stages in problem-based learning models. Researchers are the main research instrument, data obtained through several previous studies or journals about research on students' spatial abilities in terms of van hiele's think ing stages in problem-based learning. This study uses the analysis technique of the Miles and Huberman model. Data analysis activities, namely data reduction, display data, and conclusion drawing/ verification. The subjects in this study were journal articles on the analysis of students' spatial abilities in terms of van hiele's thinking stages in problem-based learning. The object of this research is the provision of a problem-based learning process. Based on the results of the study, there are students with high spatial abilities who have exploratory thinking processes, methodical thinking, analogical thinking, abstract thinking, synthesis, serendipity, and recycling ideas, students with high spatial abilities also have high imagination, students with spatial abilities are having a process exploratory thinking, serendipity, analogical thinking, semi-abstract thinking, and recycling of ideas and having moderate imagination, as well as students with low spatial abilities in understanding problems using exploratory, analogical, semi-abstract, synthesis thinking processes and have low imagery.
\end{abstract}

Keywords theory spatial mathematics ability; Van Hiele thinking; problem based learning model

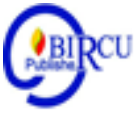

\section{Introduction}

Mathematics plays an important role in the development of science and technology in everyday life. Especially at school, Mathematics is one of the main subjects studied at every level of education from SD / MI, SMP / MTs, SMA / MA to tertiary institutions. In addition, mathematics is also a requirement with values that can shape the personality and character needed to face an era that demands professionalism. Based on this, mathematics needs serious attention.

The Indonesian government has made various efforts to improve the quality of teaching and improve student mathematics learning outcomes, because mathematics is a very important science in every level of education pursued by every Indonesian citizen. The government's efforts are to develop curricula, provide training to teachers, complete educational infrastructure and even improve teacher welfare. Along with the development of the internet, learning strategies have shifted and various information and communication technology-based learning strategies have emerged from the e-learning 
model, smart classroom technology, virtual classrooms, belded learning, etc. (Fitri \& Zahari, 2019).

Through good mathematics education, students can indeed obtain various kinds of provisions in facing challenges in the global era. Curriculums are learning guides that are governed by a school board that is designed to address students' educational needs, facilitate learners while establishing relationships between teachers and students (Campbell-Phillips, 2020). Learning is the actualization of the curriculum that requires teacher activeness in creating and growing the activities of students in accordance with the programmed plan (Sinaga, 2020). In the 2013 curriculum itself, the use of technology in learning became something that was highly recommended. The learning process in the 2013 curriculum requires students to participate actively and provide sufficient space for students' creativity, interests, and talents (Fitri, Syahputra, \& Syahputra, 2019).

Meanwhile, those around us are never separated from the role of mathematics. The difficulties experienced by students in learning mathematics because mathematics is a lesson about abstract things that are difficult to understand and boring. Besides that, the lack of the role of students in learning causes no interest in taking mathematics lessons, because students only receive the knowledge provided by the teacher. As a result, students are not able to apply theories in school to solve daily problems.

According to Hasratuddin (2015) that "mathematics is the science of logic regarding form, arrangement, quantity, other related concepts in large quantities which are divided into three fields, namely algebra, analysis, and geometry". In mathematics, the materials taught are basic sciences that are rapidly developing both in content and in application. Thus teaching mathematics in school is a priority in education. Mathematics is also very important in everyday life.

The spread of competency standards (in Febriana, 2015) for junior high school education units, which received the largest portion was geometry (41\%) compared to others such as algebra (37\%), numbers (15\%), and statistics and opportunities (7\%). Based on these data geometry has a bigger role for students than other branches of mathematics.

Based on some of the opinions above, it is stated that geometic material in mathematics has a very important role and is a very difficult material for students. Where students are not able to complete the geometrical design according to the prevailing rules.

Problem Based Learning (PBM) or in English Problem Based Learning (PBL) has been known since the days of John Dewey. PBM is a learning model that adheres to constructivism which emphasizes making students able to solve problems, especially problems of spatial ability (spatial ability). This was revealed by Trianto (2011) who said that the PBM model is based on constructivism theory. In this model learning begins by presenting real problems that solve them requires cooperation between students. This PBM model is a model that has begun to be adopted because it is generally seen that this model presents students to carry out inquiry investigations. From this explanation, this learning is expected to enable students to be actively involved in learning and students can use their own problem-solving concepts of spatial abilities they are learning. PBM can improve spatial abilities (SpatialAbility) because this learning model can make students active to participate in the learning process, namely by solving problems given in real life that attract more students to learn mathematics so that students will know that mathematics has many uses. In addition, the Problem Based Learning model is one of the learning models directed in the implementation of the curriculum in Indonesia today. Based on this thought, the researcher is interested in conducting a study entitled "Analysis of Student's spatial ability in terms of Van Hiele's Thinking Stages in Problem Based Learning" 


\section{Research Methods}

The subjects in this study were journal articles on the analysis of students' spatial abilities in terms of van hiele's thinking stages in problem-based learning. The object of this research is the provision of a problem-based learning process. Researchers are the main research instrument. So in this study, researchers act as planners, implementers of data collectors who then interpret the data that has been collected. In conducting research, researchers collect as much data as possible so that the research results are accurate. Apart from that, researchers began to read and understand several previous studies or journals about research on students' spatial abilities in terms of van hiele's thinking stages in problem-based learning. In this study, researchers used a type of literature study research, namely a series of activities related to the library data collection method, Mahmud (2011). In this study, the analysis technique used was the Miles and Huberman model. Data analysis activities, namely data reduction display data and conclusion drawing/verification.

\section{Results and Discussion}

\subsection{Results}

From several sources, experts who expressed their opinion about spatial abilities, namely some of the opinions above stated how important it is to master spatial ability in mathematics learning is one of the factors that influence student learning success. This is emphasized by Indriyani, (2013) that spatial abilities also have an influence on students' mathematical abilities. This means that if the student's spatial ability in mathematics is high, then the student's ability to do mathematics is generally high.

Several previous studies that have conducted research with the same title have obtained different results as one of the previous researchers. According to Sari (2013) who conducted a study entitled Analysis of Student's Spatial Ability and Self-efficacy in Cooperative Learning Using Jigsaw.

Students' thinking processes on spatial abilities are divided into 3 categories, namely high, medium, and low. In this study, after applying the teaching and learning process determined by the researcher, eating can show the level of students' spatial abilities which will be shown in the following table:

Table 1. Students' Spatial Mathematics Ability Level

\begin{tabular}{|c|l|c|c|l|}
\hline No. & Score Interval & The Number Of Students & Percentage & Category \\
\hline 1 & $0 \leq \mathrm{SK}<65$ & 13 & $38 \%$ & Low \\
\hline 2 & $65 \leq \mathrm{SK}<80$ & 14 & $41 \%$ & Intermediate \\
\hline 3 & $80 \leq \mathrm{SK}<100$ & 7 & $21 \%$ & High \\
\hline 3 & $80 \leq \mathrm{SK}<100$ & 7 & $21 \%$ & High \\
\hline
\end{tabular}

Based on the results of the math spatial ability test on 34 students, the students' spatial ability levels were divided into three categories. 5 students out of 34 students involved in this study were selected for the interview based on their Mathematical spatial abilities.

The results of the test were corrected by the researcher and further classified in the Van Hiele geometric thinking level distribution table. The criteria for students to be able to answer an item correctly is if the student gets a minimum score of 8 or gets $80 \%$ of the maximum item score on that item. 


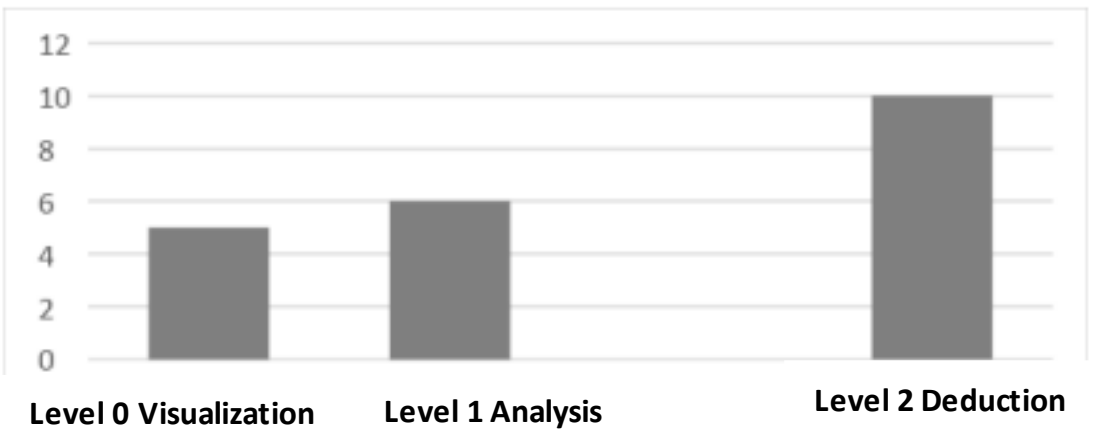

Figure 1. Distribution Results Diagram for Van Hiele Geometry Thinking Class VII B MTS Darussalam Jabon

Based on Figure 1, it can be seen that the highest distribution of students is at level 2 based on Van Hiele's level of thinking, while at level 0 and level 1 only about half of the students who have level 2.

The subject of this study was then given a test of students' mathematical problem solving abilities on the rectangular material and then analyzed according to Van Hiele's geometric thinking level. The following is the student name and coding data provided by the researcher for analysis.

Table 2. List of Research Subjects

\begin{tabular}{|l|l|c|}
\hline No & \multicolumn{1}{|c|}{ Thinking Level } & Code \\
\hline 1 & Level 1 (Visualization) & A1 \\
\hline 2 & Level 2 (Analysis) & A2 \\
\hline 3 & Level 3 (Informal Education) & A3 \\
\hline
\end{tabular}

\section{a. The Abilities Obtained by the Subject Level 0 (Visualization)}

In carrying out the problem-solving plan, subject A1 was unable to solve the problem according to the question's instructions because in the preparation of the settlement strategy there was still something missing. Subject A1 was in the rechecking stage, unable to check the results of his answers again and unable to convince himself that the results of the solutions were correct. Based on the discussion, students in group level 0 (visualization) note that in understanding the problem can be done correctly, but in compiling the plan for completion, implementing the plan for completion, and re-checking the answer cannot be done correctly.

\section{b. The Abilities Obtained by the Subject Levell 1 (Analysis)}

In carrying out the problem solving plan, subject $\mathrm{A} 2$ is able to solve the problem in accordance with the solution strategy by using the correct settlement steps and the calculation process for each step is also correct. Subject A2 at the rechecking stage, has not been able to re-check the results of his answers, is unable to determine how the steps are in re-examining the results of his work. Based on this discussion, students at level 1 (analysis) note that in understanding the problem, compiling a solution plan, and implementing the problem solving plan have been done correctly. However, students have not been able to check the results of their answers again even though the calculations have been done correctly. 


\section{c. The Abilities Obtained by the Subject Level 2 (Informal Deduction)}

In carrying out the problem solving plan, the A3 subject is able to solve problems according to the correct resolution strategy and the correct calculation process. Subject A3 is in the rechecking stage, is able to check the results of their answers again and is able to convince themselves that the results of their solutions have been done correctly. Based on this discussion, students at level 2 (informal deduction) note that in understanding the problem, compiling a problem-solving plan, executing the solution plan, and checking again can be done correctly and the calculation process is also carried out correctly.

Siagian (2019) conducted a study with the title analysis of the difficulty of solving geoetric problems for class VIII students of SMP Methodist 7 Medan in terms of van Hiele's theory of thinking assisted by Macromedia Flash. This research is a qualitative descriptive study. Learning carried out assisted by macromedia flash.

The research data were obtained directly from the research subjects, namely in the form of work sheets on the students' geometry problem-solving abilities, the results of the learning media questionnaire test results and recorded interviews. The data that will be presented in this research are Van Hiele's geometry thinking level, the level of students 'geometry problem solving ability, and a description of the researcher interview with students. Then from the existing data, data triangulation is carried out to analyze students' difficulties in solving geometric problems which refer to the patron of problem solving difficulties. Students 'geometry. Through the data analysis, it can be concluded that new findings are drawn. Conclusion is to describe the students' difficulties in solving the geometry problems under review and student work sheets and researcher interviews with students. follows :

In the following table the geometric thinking levels of students are described as

Table 3. Students' Levels of Geometry Thinking

\begin{tabular}{|c|l|c|}
\hline Level & \multicolumn{1}{|c|}{ Number of Students Based on Absent Number } & $\begin{array}{c}\text { The Number of } \\
\text { Students }\end{array}$ \\
\hline 0 & $1,2,3,4,5,6,7,8,9,10,11,12,13,14,15,16,17,18,19,20,21,22,23,24,25,26$ & 26 \\
\hline 1 & $1,2,3,5,6,7,8,9,10,11,12,13,15,16,18,19,20,22,23,24,25,26$ & 21 \\
\hline 2 & $1,2,3,5,6,7,8,9,11,13,18,19,20,23,26$ & 13 \\
\hline 3 & $2,3,13,2,23,26$ & 6 \\
\hline 4 & - & - \\
\hline
\end{tabular}

In Table 3, the results of the grouping of gometric thinking levels of students who are registered based on the student serial number are presented. The table above shows that there is a reduction in the number of students who can achieve the lowest to the highest level of geometric thought. So it can be concluded that the higher the level of thinking geometry, the fewer students will be able to achieve it.

Table 4. Results of Students' Geometry Problem Solving Ability Tests

\begin{tabular}{|l|l|c|c|c|}
\hline No. & Interval SKPMG & $\begin{array}{c}\text { The Number of } \\
\text { Students }\end{array}$ & Percentage & Level \\
\hline 1 & $0 \leq$ SKPMG $<65$ & 13 & $50 \%$ & Low \\
\hline 2 & $65 \leq$ SKPMG $<80$ & 7 & $26,92 \%$ & Medium \\
\hline 3 & $\begin{array}{l}80 \leq \text { SKPMG } \\
100\end{array}$ & 6 & $23,08 \%$ & High \\
\hline
\end{tabular}


After the trial was carried out, a score was given to the student's work, then it was obtained as in the table above.

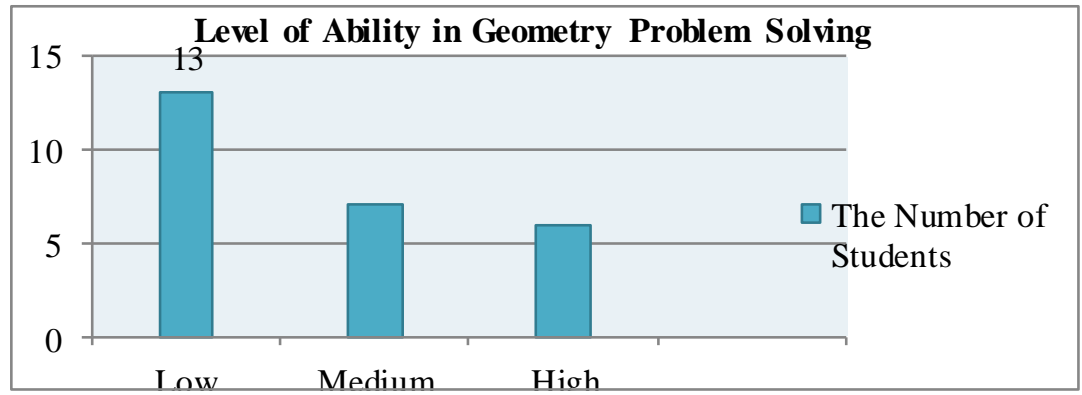

Figure 2. Diagram of the Level of Troubleshooting Ability

In Figure 2, many students who have a minimum level of gometric mass solving ability are 13 students and many students who have a low level of geometric problem solving ability are 13 students because there are many students who have a low level of geometric problem solving ability, which shows that there are still many students who do errors in solving geometry problems. So it is necessary to explore the difficulties experienced by students who make mistakes in solving geometry problems.

Nur'ani Muhassanah (2014) in his research entitled Analysis of students' geometric skills in solving geometric problems based on van hiele's level of thinking. The qualitative research method is a case study type, which analyzes students' geometric skills in solving geometry problems based on van hiele's level of thinking in depth.

Researchers determine the research subjects using purposive sample. To determine the subject, the researcher gave a placement test to 28 students of class VIII SMP N 16.

Based on the results of the analysis on the results of interviews conducted 18 times 9 subjects, the characteristics of students' geometric skills in solving geometry problems were obtained based on van hiele thinking level for level 0 (visualization), level 1 (analysis), and level 2 (informal education).

\subsection{Discussion}

a. Geometry Skills at Level 1 (Analysis)

1. Visual skills

It can only determine the type of flat shape of a quadrilateral based on the appearance of its shape and the properties it has, in explaining the properties of a quadrilateral based on the image it can explain the specifics which include the number of sides, side size, angle size, side alignment, and the relationship between the two angles. facing the same size, and cannot explain the relationship between the various types of rectangular images.

2. Verbal skills (descritive skills)

Can group the correct names for given quadrilateral images, can describe / define a quadrilateral based on the properties it has from the number of sides, side size, angle size, number of angles, side alignment, and cannot formulate sentences that indicate the relationship between the rectangular images.

3. Drawing skills

Be able to construct images according to the characteristics and properties given such as two parallel lines, two perpendicular lines and determine a point in a line, and able to construct other rectangular images related to the given rectangular image and can describes the properties of the quadrilateral starting from the side dimensions. 
4. Logical skills

Be able to understand the conservation of the shape of a rectangular image in various positions by mentioning the type of each image, be aware of the similarities of several quadrilateral images starting from the same shape as rectangles and the number of sides, and be able to mention the differences in rectangles and realize that properties can be used to distinguish types of rectangles, starting from the size of the side, the size of the angle and the number of sides that are parallel.

5. Applied skills

Can relate information (physical objects) given and develop it in a geometric model (without using scale), can explain the geometric properties of physical objects, and can use geometric models in solving problems.

\section{b. Geometry Skills at Level 2 (Informal Education)}

1. Visual skills

The visual skills possessed include the subject being able to group and determine the type of rectangular shape in each image based on the properties of each image, in explaining the properties of a rectangular shape based on the image can explain specifically which includes the number of sides, side size, the alignment of sides, the size of the angles, the relationship between two facing angles of equal size, the number of angles, the relationship between adjacent angles totaling $180 \mathrm{o}$, and can explain the relationship between various types of rectangular images based on the properties of each image and recognize the general nature of various types of rectangular images by sorting out which ones fall into the general nature or not.

2. Verbal skills (descritive skills)

Subjects can classify the correct names for the given quadrilateral images, can describe / define a rectangular shape based on the properties they have from the number of sides, side size, angle size, number of angles, side alignment, and the relationship between the two angles. facing the same size, the relationship between adjacent angles has $180 \mathrm{o}$ number of angles, and can formulate a sentence that shows the relationship between the quadrilateral based on the general properties possessed by the quadrilateral.

3. Drawing skills

Subjects are able to construct images according to the characteristics and properties given such as two parallel lines, two perpendicular lines and determine a point in a line and are able to construct another rectangular image related to a given rectangular image (rectangle, square, right-angled trapezoid) is even able to make guide lines to form another rectangle (line of ranks), and can explain the properties of the image of the rectangle it forms.

4. Logical skills

Subjects can understand the conservation of the shape of a rectangular image in various positions by mentioning the type of each image, realizing the similarities of several rectangular images starting from the same shape as rectangles, the number of sides, and the number of angles, can mention the difference in rectangles and realize that properties can be used to distinguish the type of rectangle, starting from the size of the angle, the size of the side and the number of pairs of sides that are parallel, and can use the properties of a rectangular drawing to determine a class of rectangles contained in other types of rectangular classes.

5. Applied skills

The applied skills possessed by each category of van Hiele's thinking level are 
different, where there are similarities and differences in the applied skills possessed by each level.

According to Harina et al (2018) conducted a study with the title knowing the geometric development of students. This type of research is a descriptive study with a qualitative approach. Data collection techniques in this study consisted of two methods of test and interview. The instrument used was a test consisting of 25 multiple choice items. Data analys is used Miles and Huberman's model.

The results showed that the geometric thinking level of mathematics education students was at level 0 (visualization), level 2 (analysis), level 2 (informal deduction), and level 3 (formal deduction). On the other hand, no one has yet reached level 4 (rigor). The number of students who were difficult and could not be classified or identified was significant enough to be at the pre-visualization level (before visualization). Table 5 shows the results of the data analysis on the level of development of students' geometric thinking.

Table 5. Student's Level of Geometric Thinking Development

\begin{tabular}{|l|l|}
\hline \multicolumn{1}{|c|}{ Tingkat } & Percentage \\
\hline Previsualization & $30,65 \%$ \\
\hline Level 0 & $21,51 \%$ \\
\hline Level 1 & $29,03 \%$ \\
\hline Level 2 & $16,67 \%$ \\
\hline Level 3 & $2,15 \%$ \\
\hline Level 4 & $0,00 \%$ \\
\hline Total & $\mathbf{1 0 0 , 0 0 \%}$ \\
\hline
\end{tabular}

Based on Table 5, most of the mathematics education program students are at level 1 (analysis). Only a few students (2.15\%) have met level 3 (deduction), while there are no students who meet level 4 (rigor) $(0 \%)$, and $30.67 \%$ are not at the level of van hiele geometry development. This data shows that most of the development of students 'geometric thinking is at the level of analysis, namely understanding the concept of geometry is carried out by informal analysis of parts of geometric objects, students' ability in deductive thinking is still weak. For the sixth semester, all geometry courses consisting of geometry, space geometry, field analytic geometry, space analysis and transformation geometry are expected to be at a higher level than these results. Especially if the student has taken an optional course in the geometry system. Ideally, their level of geometric development is already at the top level. This shows that learning activities in geometry courses need to be improved so that the development of students' geometric thinking can be boosted.

Table 6. Transition Levels between Student Geometry Development Levels

\begin{tabular}{|c|c|c|}
\hline Transition Rate & f & \% \\
\hline Pra 1 & 32 & $17,20 \%$ \\
\hline Pra 2 & 25 & $13,44 \%$ \\
\hline Pra 3 & 12 & $6,45 \%$ \\
\hline Pra 4 & 2 & $1,08 \%$ \\
\hline Total & 71 & $38,17 \%$ \\
\hline
\end{tabular}

In table 6 , the percentage of the highest transition level at the pre-1 level (preanalysis) is $17.2 \%$ and the lowest percentage at the pre-rigor level is $1.08 \%$. Students who 
have reached the transitional level can increase their geometric level through learning that supports increased geometric thinking. In addition, students who are at the transitional level, there are also students who have difficulty classifying their level of geometric thinking as many as 75 students $(40.32 \%)$. This is because the respondent is not serious in working on the questions given so that they answer randomly or cheat while working on the questions, or it could be because the development of their geometrical thinking has not met any level in Van Hiele's theory.

Analysis of the Spatial Ability of Class VII Students of SMP N 2 SAWIT in Solving Quadrangular Material Questions Based on Van Hiele's Thinking Level

The research data were obtained through three methods, namely the test method, interview method and documentation method. The test was held on Monday, August 7 2017 in class VII D which was attended by 21 students. The test is in the form of an essay which consists of 3 questions.

The selection of subjects in this study was taken from 21 students of class VII D who took the written test and were classified based on the minimum completeness criteria (KKM) as follows.

Table 7. Grouping of Prospective Research Subjects

\begin{tabular}{|c|l|c|}
\hline $\begin{array}{c}\text { Value } \\
\text { Range }\end{array}$ & \multicolumn{1}{|c|}{ Information } & $\begin{array}{c}\text { The Number of } \\
\text { Students }\end{array}$ \\
\hline $76-100$ & Abovethe KKM & 5 \\
\hline 75 & Right KKM & 3 \\
\hline $0-74$ & Under the KKM & 15 \\
\hline
\end{tabular}

Through this grouping, 3 students were selected as research subjects, namely one student from the high spatial ability category, hereinafter referred to as an undergraduate student, one student from the medium spatial ability category, hereinafter referred to as a master's student, and one student with low spatial ability furthermore. referred to as doctoral students.

Table 8. List of Student Names Selected for Interview

\begin{tabular}{|lr|l|c|}
\hline \multicolumn{1}{|c|}{ Subject } & \multicolumn{1}{|c|}{ Name } & $\begin{array}{c}\text { Student Spatial } \\
\text { Ability }\end{array}$ \\
\hline $\begin{array}{l}\text { Subject } \\
\text { (S1) }\end{array}$ & 1 & $\begin{array}{l}\text { Ayesha Frisky Nur } \\
\text { C }\end{array}$ & High \\
\hline $\begin{array}{l}\text { Subject } \\
\text { (S2) }\end{array}$ & 2 & Galih D.W & Medium \\
\hline $\begin{array}{l}\text { Subject } \\
\text { (S3) }\end{array}$ & 3 & Umi Nur Hasanah & Low \\
\hline
\end{tabular}

\section{c. Level of Visualization}

At the visualization level, undergraduate students are familiar with geometric shapes and are able to name a geometric shape. This is indicated by the student being able to describe a rectangular shape object on the student's answer sheet. This means that students who have high spatial abilities have reached the visualization level. 


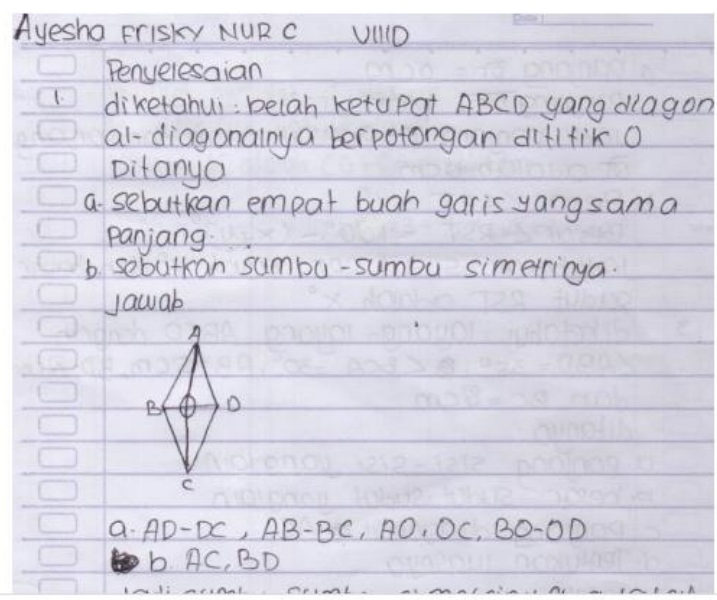

Figure 3. Answers of Students with High Spatial Ability in Visualization Level

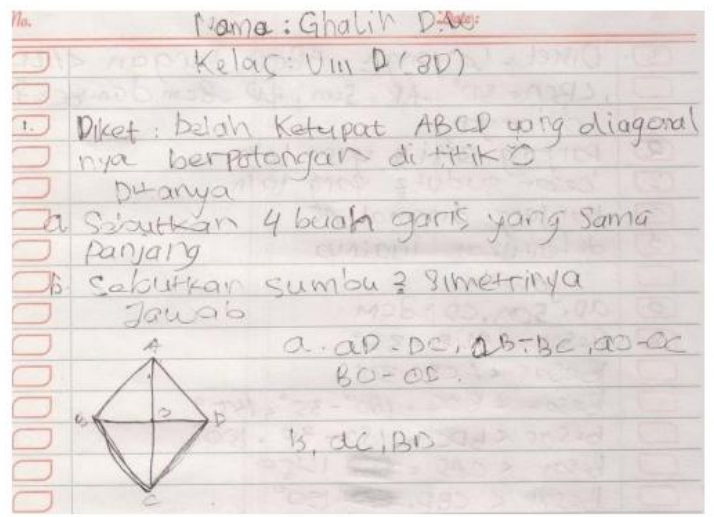

Figure 4. Students' Answers with Moderate Spatial Ability in Visualization Level

Based on the students' answers from Figure 2, it appears that students who have moderate spatial abilities can already visualize rectangular objects. Students have identified a shape based on the shape or characteristic they know. This means that students with moderate spatial abilities can reach the Visualization level.

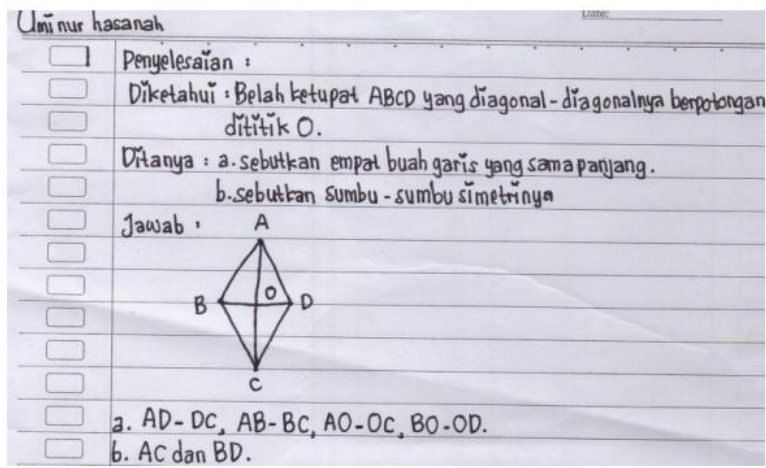

Figure 5. Answers of Students with Low Spatial Ability Level of Visualization

Based on the students' answers from Figure 3, it appears that doctoral students can already understand the questions. The student can already visualize the rectangular shape by drawing on the answer sheet. Doctoral students can already identify shapes based on the shape or nature they know. This means that students who have low spatial abilities can reach the Visualization level. 
The results of the research above indicate that students who have high, medium and low abilities have reached the Visualization level. This is in line with the results of research conducted by Nur'aini (2015) which revealed that students at level 0 (visualization) on visual skills can only determine the type of flat rectangular shape based on the appearance of the shape; verbal skills, can group the correct name for the pictures given rectangle; drawing skills, only able to sketch rectangular images with labeling of certain parts; logical skills, can understand the conservation of rectangular image shapes in various positions and realize the similarities of several rectangular images; and applied skills, can relate information (physical objects) provided and develop it in a geometric model, in addition to explaining the geometric properties of physical objects. This opinion was later strengthened by research conducted by Wahab (2016) which stated that of the 133 respondents the majority of students had reached level 1 (visualization).

\section{d. Levels of Analysis}

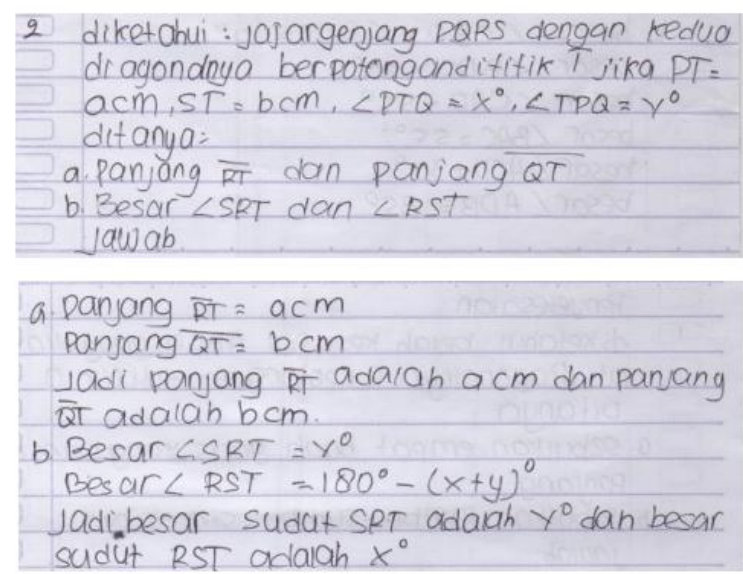

Figure 6. Answers of Students with High Spatial Level of Analysis Ability

At the level of analysis, undergraduate students have memorized the properties of geometric shapes and the attributes of their components. This is indicated by the student being able to do the problem correctly. It means that undergraduate students already understand the questions given. Thus $\mathrm{S} 1$ has reached the Analysis level.

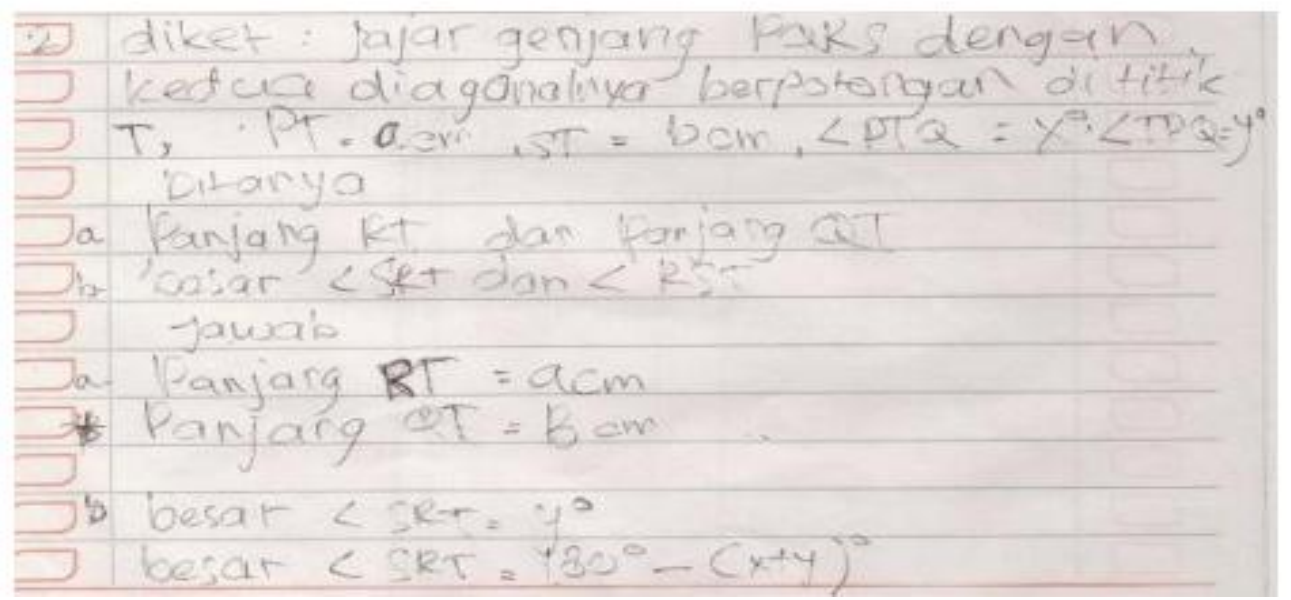

Figure 7. Answers of Students with Moderate Spatial Ability Level of Analysis 
Based on the students' answers from Figure 5, it appears that students who have moderate spatial abilities already understand the questions. This is indicated by students being able to identify shapes based on their shape or what they know. Students can already describe a geometric shape based on the properties or attributes of its components. This means that students who have moderate spatial abilities have reached the level of analysis.

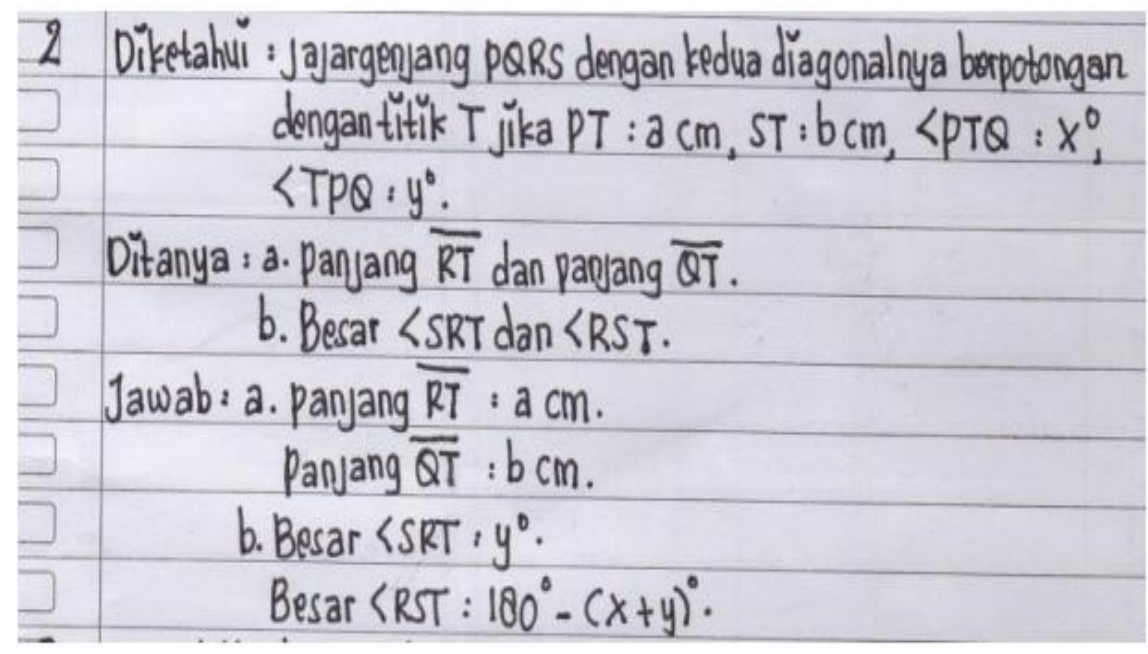

Figure 8 Answers of Students with Low-Level Spatial Ability for Analysis

Based on the students' answers from Figure 6, students who have low spatial abilities can work on the questions correctly. However, during the interview session, doctoral students could not answer the questions asked in question number $2 \mathrm{~b}$. This is indicated by the student's statement that "Don't understand, sir. Because I'm still confused about the corners, sir. "This means that doctoral students have not been able to identify a shape based on its shape or nature. Students have not been able to describe a geometric shape based on the properties and attributes of its components. This means that students who have low spatial abilities have not yet reached the level of analysis.

Subject 2 who has moderate mathematical ability, the description of Van Hiele's geometric thinking level at the recognition level (0) is that the subject is able to recognize the structure of the shape and name the shape, for the level of analysis (1) is able to realize the properties of the shape. The level of informal deduction (2) is being able to make a statement that there is a shape that is interconnected with other shapes. Subject 3 has low mathematical ability, the description of Van Hiele's geometric thinking level is at the recognition level (0), which is able to visually recognize shape characteristics, and give names.

\section{e. Levels of Informal Deduction}

Based on the answers of undergraduate students from the picture above, these students can understand the questions well. Students can compare geometric shapes based on their properties. Students can also solve problems that involve familiar wake-up properties. Students can also apply the formulas and solve these questions on the answer sheet. This means that students who have high spatial abilities have reached the level of Informal Deduction 


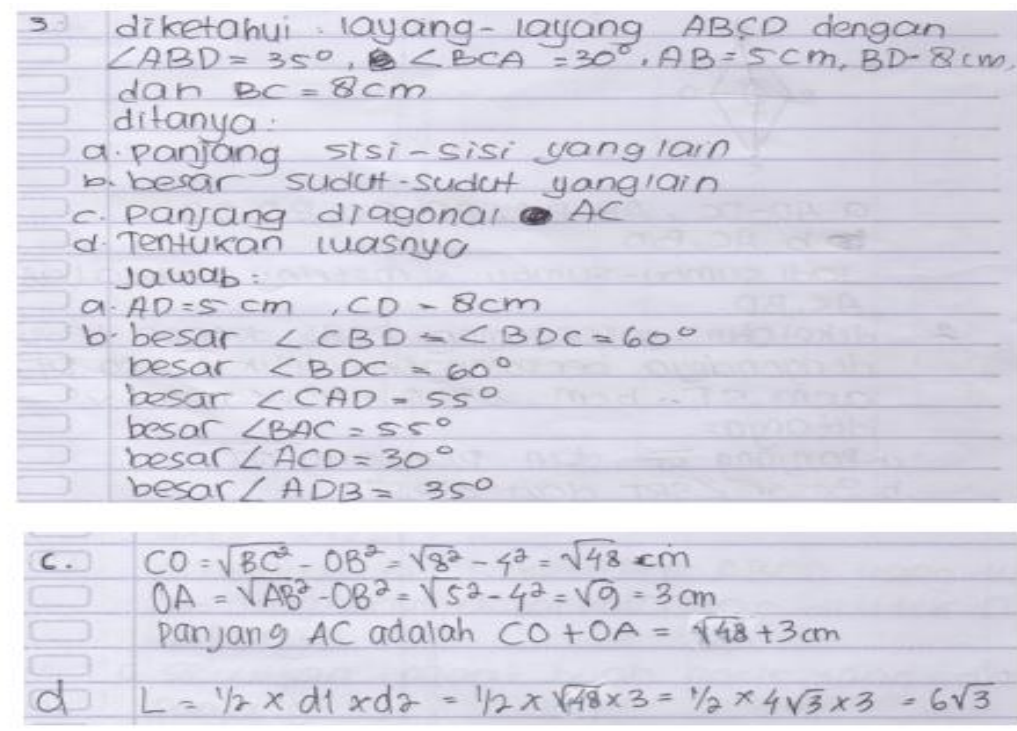

Figure 9. Answers of Students with High Spatial Ability in the Level of Informal Deduction

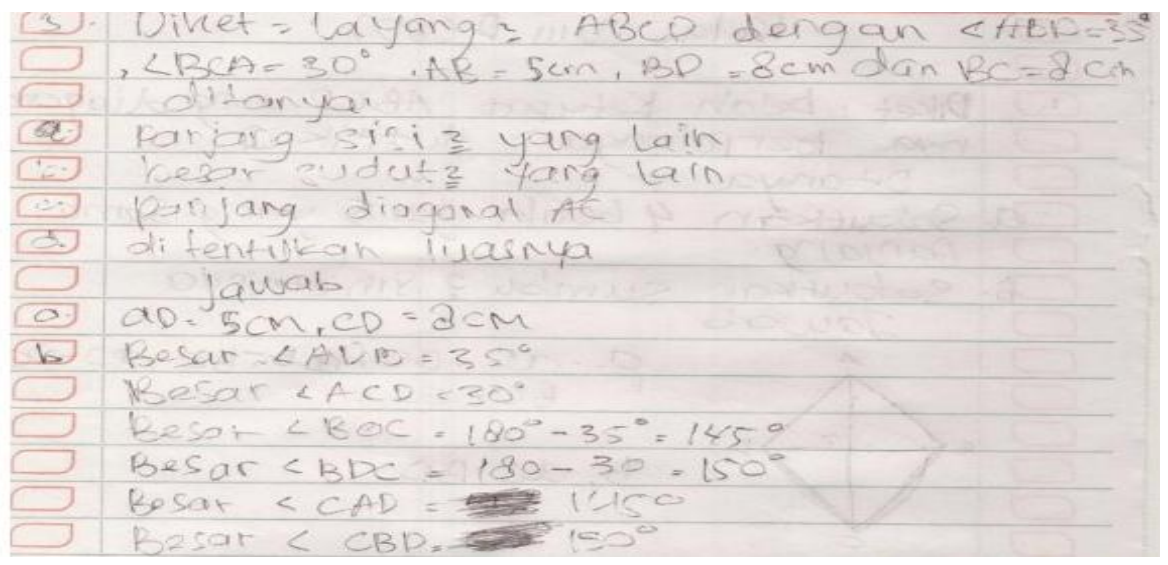

Figure 10. Answers of Students with Moderate Level of Informal Deduction

Based on the answers of S2 students from Figure 8 it appears that students with moderate spatial abilities are still having difficulty working on the questions given. Students have not been able to compare geometric shapes based on their properties. Students also have not been able to solve problems related to the questions given. This is indicated by students who are still confused about the angles of geometric shapes. This means that students who have moderate spatial abilities have not yet reached the level of informal deduction.

\begin{tabular}{|c|c|}
\hline 3 & Diketahŭ = Layang - layang $A B C D$ dengan $\angle A B D=35^{\circ}, \angle B C A=30^{\circ}$, \\
\hline$\square$ & $A B=5 \mathrm{~cm}, B D=8 \mathrm{~cm}$, dan $B C=8 \mathrm{~cm}$. \\
\hline$\square$ & Vitanya : a. panjang sisiyang lain. \\
\hline$\square$ & b. besar sudut-sudut yang lain. \\
\hline$\square$ & c. Panjang diagonal AC. \\
\hline$\square$ & d. Tentukan luasnya. \\
\hline$\square$ & Jawab : $a \cdot A D=5 \mathrm{~cm}, C D=8 \mathrm{~cm}$. \\
\hline
\end{tabular}

Figure 11. Answers of Students with Low Spatial Ability in Informal Deduction Levels 
Based on the answers of S3 students from Figure 9 it appears that S3 is still having difficulty in solving the problems in the questions given. This is indicated by students who cannot do several points on the questions. Students also cannot yet compare geometric shapes based on their properties. This means that students with low spatial abilities have not been able to reach the level of Informal Deduction.

Indicators of informal deduction can only be achieved by students who have high spatial abilities. Undergraduate students can understand the questions well. S1 can relate the properties of a flat shape with its application to the flat shape formulas. Meanwhile, students who have moderate spatial abilities and students who have low spatial abilities have not been able to reach the level of informal deduction. This is indicated by students who have moderate and low spatial abilities who still have difficulty solving problems. This is in accordance with research conducted by Suwito, et al. (2014) which states that the results of this study concluded that students who reach the level three van Hielle level are able to solve geomertial algebra problems correctly by utilizing the deduction of spatial reasoning ability to build geometric structures in axiomatic systems. in solving a given problem. Then this is also in accordance with the results of research conducted by Febriana (2015) which states that students with moderate abilities have difficulty in representing the spatial images in their minds in the field. Meanwhile, low-ability students have difficulty imagining object shapes from different perspectives. This opinion is reinforced by the results of research from Jogymol K. Alex (2016) which reveals that rectangular flat shapes namely rhombus, kites and trapezoid are considered to be problems for students.

\section{f. Analysis of Student Spatial Ability in terms of Van Hiele's Thinking Stages in Problem Based Learning}

This research is to determine the analysis of students' spatial abilities in terms of Van Hiele's thinking stages in problem-based learning, after analyzing various sources taken such as books, articles, journals and previous research, we can see that problem-based learning with Van Hiele's thought process. students 'spatial abilities greatly affect the improvement of students' abilities. From several research findings in the field, namely the difficulty of the problem solving process in spatial abilities. And the thinking process of students at Van Hiele's thinking stage still reaches level 3 (deduction).

\section{Conclusion}

The Based on the results of data analysis and discussion in this study, the following conclusions are stated:

1. Students' thinking processes on spatial abilities after problem-based learning by following Van Hiele's thought process are categorized into three categories, namely high, medium low as follows:

a. Students with high spatial abilities have a process of exploratory thinking, methodical thinking, analogical thinking, abstract thinking, synthesis, serendipity, and recycling of ideas. Students with high spatial abilities also have high imagination.

b. Students with moderate spatial abilities have an exploratory thought process, serendipity, analogical thinking, semi-abstract thinking, and recycle ideas and have a moderate imagination.

c. Students with low spatial abilities in understanding problems use exploratory, analogical, semi-abstract, synthesis thinking processes and have low imagination. 


\section{References}

Abduh, M, 2017. Interaksi Pada Pendekatan Saintifik (Kajian Teori Scaffolding). Seminar Nasional Pendidikan PGSD UMS \& HDPGSDI Wilayah Jawa. ISBN 978-60270471-2-9.

Alex, Jogymol K. and Mammen, Kuttickattu J. 2016. "Geometrical Sense Making: Findings of Analysis Based on the Characteristics of the van Hiele Theory among a Sample of Sounth African Grade 10 Learners.'Eurasia Journal of Mathematics, Science \& Technology Education 12(2): 29-39.

Champbell-Phillips, S. (2020). Education and Curriculum Reform: The Impact They Have on Learning. Budapest International Research and Critics in Linguistics and Education (BirLE) Journal Vol 3 (2): 1074-1082.

Clements, D.H. \& Battista, M.T. 1992. Geometry And Spatial Reasoning. Dalam Grouws, D. A. Hanbdbook of reseach on Mathematics Teacing and Learning. New York: MacMillan Publising Company.

Crowley, M.L.1987. The Van hiele Model of the Development of Geometric Thought . Dalam Lindquist, M.M and Shulte, A.P. (Eds.), Learning and Teaching Geometry, K12, (pp. 1-16). Reston VA: National Council of Teachers of Mathematics

Farisdianto, D., dan Budiarto, M. (2014). Profil Kemampuan Siswa SMP dalam Menyelesaikan Masalah Geometri ditinjau dari Perbedaan Kemampuan Matematika. Mathedunesa Jurnal Ilmiah Pendidikan Matematika. Volume 3 No. 2.

Febriana, Evi. 2015. Profil Kemampuan Spasial siswa Menengah Pertama (SMP) dalam menyelesaikan Masalah Geometri Dimensi Tigaditinjau dari Kemampuan Matematika. Jurnal elemen 1(1): 13 - 23.

Fitri, S., \& Zahari, C.L. 2019.- The implementation of blended learning to improve understanding of mathematics\|, The Sixth Seminar Nasional Pendidikan Matematika Universitas Ahmad Dahlan 2018: IOP Conf. Series: Journal of Physics: Conf. Series 1188 (2019) 012109, 2018, doi:10.1088/1742-6596/1188/1/012109.

Fitri, S., Syahputra, E., \& Syahputra, H. 2019. "Blended Learning Rotation Model of Cognitive Conflict Strategy to Improve Mathematical Resilience in High School Students", International Journal of Scientific \& Technology Research, vol.1, no. 1.

Hasratuddin. 2015. Mengapa Harus Belajar Matematika. Medan: Perdana Publishing. Education (IJARIIE) ISSN 2395-4396

Indriyani, E. 2013. Perbedaan Peningkatan KemampuanSpasialdan Disposisi Matematis Siswa yang Diberi Pembelajaran Geometri Berbasis Teori Van Hiele dengan dan Tanpa Aplikasi Wingeom di SMP Negeri 4 Binjai. Program PascaSarjana Jurusan Pendidikan Matematika Universitas Negeri Medan : Medan.

Ismail. 1998. Kapita Selekta Pembelajaran Matematika. Universitas Terbuka.

Mahmud, (2011). Metode Penelitian Pendidikan. Bandung: Pustaka Setia.

Mayberry. 1983. Perancangan dan implementasi Perangkat Ajar Geometri SMTA. Jakarta. PPS UI

Nasution, T. K. 2017. An Analysis of Syudent's Mathematical Creative Thinking Ability Senior High School on Geometry. IJARIIE - ISSN(O) - 2395 - 4396. Vol - 3 Issue - 2 2017, pp: 3860-3866.

Sari, N. (2013). Pengaruh Pembelajaran Berbasis Masalah Terhadap Kemampuan Pemecahan Masalah dan Kemandirian Belajar Matematis Pada Mahasiswa STMIK di Kota Medan. Tesis. Medan: Pascasarjana UNIMED.

Siagian,P.G.G 2019. Analisis Kesulitan Pemecahan Masalah Geometri Siswa Kelas VIII SMP Metodist 7 Medan Ditinau Dari Tahapan Berpikr Van Hiele Berbantuan 
Macromedia Flash, Tesis. Universitas Negeri Medan. Medan

Sinaga, A.I., Salamuddin, and Khairini, D. (2020). Patterns of Islamic Education Learning in Applying 2013 Curriculum in SMPN 27 Medan. Budapest International Research and Critics in Linguistics and Education (BirLE) Journal Vol 3 (3): 1551-1557.

Suparyan. 2007. KajianKeruangan (Spasial Abilities) Dan Kemampuan Penguasaan Materi Geometri Ruang Mahasiswa Program Studi Pendidikan Matematika FMIPA Universitas Negeri Semarang.

Syahputra, E. 2013, Peningkatan Kemampuan Spasial siswa melalui Penerapan Pembelajaran Matematika Realistik.Cakrawala Pendidikan., November 2013 Th XXXII ,No. 3

Trianto.2011.Pengantar Penelitian Pendidikan bagi Pengembangan Profesi Pendidikan dan Tenaga Kependidikan. Jakarta :Kencana Perdana Media Group. 